during the next three or four years.

The mandate of the Thulin commission was to assess the effectiveness of publicly

\section{Plutonium deal}

The United States is seeking plutonium from Britain to meet the shortages caused by the expanding US nuclear weapons programme. The US Department of Energy has approached its opposite number in Britain through the British Foreign Office with a request for plutonium reprocessed from spent reactor fuel at the Sellafield plant in Cumbria (previously called Windscale).

Negotiations are only at a preliminary stage. How much plutonium is at issue, the price, when it would be needed and the ratio of isotopes it would contain are uncertain. But, according to the British Foreign Office, negotiations concern only reactor grade plutonium for civil uses, in particular for the prototype fast breeder reactor at Clinch River, Tennessee, which the Reagan Administration hopes to persuade Congress to complete. Any agreement, says the Foreign Office, would comply with international safeguards.

The argument goes that the deal will allow the US Department of Energy to release plutonium from civil uses for nuclear weapons production. A shortage of weapons-grade plutonium by the end of the decade was forecast by the Carter Administration in its last few months of office. Hence output from reactors at Savannah River dedicated to weapons-grade plutonium production has been stepped up and another reactor will be reopened in 1984 after 13 years.

The nuclear reactor in Richland, Washington, previously dedicated to producing fuel-grade plutonium for civil use, is also being adapted to weapons-grade production. When conversion is complete in about two years' time, the stock of fuel-grade plutonium will be about 17 tons, sufficient to supply the civil programme including Clinch River until 1990. The three alternatives for ensuring supply beyond 1990 are imports, production from new equipment which could be built at Savannah River, and reprocessing spent fuel from commercial reactors. Although the Reagan Administration plans to resume reprocessing, the proposal has not yet gone to Congress.

British exports of plutonium are not unprecedented. Since 1971, Britain has exported a total of $1,280 \mathrm{~kg}$ for civil purposes to several countries including the United States. And it has also exported an unspecified amount to the United States under a military assistance agreement which came into force in 1959, in exchange for enriched uranium and tritium for use in Poseidon and Polaris missiles. financed technological research in an economy increasingly dominated by the North Sea oil sector but otherwise plagued by high costs and declining productivity. Industrial research is dominated by the Royal Norwegian Council for Scientific and Industrial Research (NTNF), which naturally came under the closest scrutiny.

Although much of Norway's technological research is financed directly by industry or government outside the NTNF system, each year some $£ 80$ million of public funds is channelled through NTNF to institutes wholly or partly owned by the council. In its report to the Norwegian Minister for Industry, the Thulin commission argues for NTNF to be given greater powers to decide how and where funds are to be allocated - the commission, NTNF and its constituent institutes are all critical of the recent trend for the four ministries sponsoring NTNF to earmark funds for particular projects rather than allow NTNF to decide on distribution. The commission concludes that the ministries do not have the scientific expertise required for this task.

To help NTNF to concentrate on "strategic" decisions, the commission suggests that the burden of short-term control should be transferred to the institutes themselves, by turning them into independent units funded by NTNF. This is radical surgery but NTNF, according to its managing director Gudmund Harlem, is not in principle opposed to such a move.

The council is already considering revamping its many coordinating committees in the direction of another of the commission's suggestions, namely to integrate them into one large "industry committee". This, though, is a sensitive area, since these committees are NTNF's pride and joy, on which representatives of industry, the ministries, local government, the institutes, universities and institute employees meet and provide a generally effective forum for discussing industrial research.

The most dramatic proposal in Tulin's report is a doubling of total national industrial research spending in the next few years. Norway's industrialists are taken to task for not spending enough on research and it is from the industrial sector that most of the new money should come, according to the commission, with the emphasis on applied rather than pure research.

The radical changes in the system proposed in the commission's report have, not surprisingly, met with opposition from many quarters, particularly from some of the pioneers of Norwegian industrial research in the late forties and fifties NTNF itself was set up in 1946 and has been steadily increasing in size and influence since then. But it is difficult to believe that change will not be forced on a system which must somehow keep pace with increasingly unpleasant economic realities. Whether the new conservative government, for all its sympathy for industry, can find the means remains to be seen.

\section{Badger tuberculosis Bring in your dead}

The British agriculture ministry is appealing to the public to notify sightings of badger carcasses which it will then test for infection with bovine tuberculosis. This latest move to increase the number of notifications, first requested in 1976, comes on the heels of the ministry's announcement that it has resumed gassing badgers suspected of passing on tuberculosis to cattle.

The gassing of infected badger setts was suspended in September 1979 pending the outcome of a review of the practice by Lord Zuckerman, president of the Zoological Society of London. The gassing began in 1975 as a means of controlling the unusually high incidence of tuberculosis in cattle in South-West England. Since then, the precise nature of the link between the disease in badgers and sporadic outbreaks in cattle has been hotly disputed. Lord Zuckerman, whose review of the largely circumstantial evidence for such a link found that gassing badgers is an effective way of minimizing outbreaks in cattle, recommended in October 1980 that gassing be resumed as soon as possible.

The ministry lost little time. Details of gassings in the last two months of 1980 are contained in a recently published report, Bovine Tuberculosis in Badgers, prepared by the ministry as part of its new obligation to publish annual reports on the progress of the control programme. In November and December 1980 the ministry authorized the gassing of previously untreated badger setts in 12 out of 26 areas in South-West England reporting new outbreaks of tuberculosis in cattle.

The ministry's report supports Lord Zuckerman's findings that bovine tuberculosis, which had declined in the most affected areas during the earlier gassing programme, increased last year during the ban. The number of new outbreaks, however, varied considerably between areas, the hardest hit counties being Devon, with three serious new outbreaks, and Cornwall, which had more infected cattle than at any time since 1976. Although infected badgers were found near these areas, none was found near outbreaks in Somerset and Wiltshire. As many as 24 per cent of dead badgers collected in the worst affected areas of Devon were found to be infected with tuberculosis compared with 9 per cent for the SouthWest as a whole.

Isolated cases of other infected mammals, in particular foxes, moles and rats, have also been found, but the ministry thinks they are unlikely to be a real threat to cattle. In the meantime, therefore, it intends to continue to monitor the incidence of tuberculosis in badgers with the public's help, and will investigate routes of transmission to cattle.

Judy Redfearn 